\title{
Significant Association of Cyclin D1 Promoter Genotypes With Asthma Susceptibility in Taiwan
}

\author{
CHIA-HSIANG LI ${ }^{1,2 *}$, KUO-LIANG CHIU ${ }^{3,4^{*}}$, TE-CHUN HSIA ${ }^{2,5^{*}}$, TE-CHUN SHEN ${ }^{2,5}$, LI-HSIOU CHEN ${ }^{1,3}$, \\ CHIEN-CHIH YU ${ }^{5,6}$, MEI-CHIN MONG ${ }^{7}$, WEN-SHIN CHANG ${ }^{1,5}$, CHIA-WEN TSAI $^{1,5}$ and DA-TIAN BAU ${ }^{1,5,8}$ \\ ${ }^{1}$ Graduate Institute of Biomedical Sciences, China Medical University, Taichung, Taiwan, R.O.C.; \\ ${ }^{2}$ Division of Pulmonary and Critical Care Medicine, Department of Internal Medicine, \\ China Medical University Hospital, Taichung, Taiwan, R.O.C.; \\ ${ }^{3}$ Division of Chest Medicine, Department of Internal Medicine, \\ Taichung Tzu Chi Hospital, Taichung, Taiwan, R.O.C.; \\ ${ }^{4}$ School of Post-Baccalaureate Chinese Medicine, Tzu Chi University, Hualien, Taiwan, R.O.C.; \\ ${ }^{5}$ Terry Fox Cancer Research Laboratory, Department of Medical Research, \\ China Medical University Hospital, Taichung, Taiwan, R.O.C.; \\ ${ }^{6}$ School of Pharmacy, China Medical University, Taichung, Taiwan, R.O.C.; \\ ${ }^{7}$ Department of Food Nutrition and Health Biotechnology, Asia University, Taichung, Taiwan, R.O.C.; \\ ${ }^{8}$ Department of Bioinformatics and Medical Engineering, Asia University, Taichung, Taiwan, R.O.C.
}

\begin{abstract}
Background/Aim: The molecular mechanisms underlying the association between cell cycle and asthma are poorly understood, and cyclin D1 (CCND1) is found to be upregulated in asthma airway smooth muscle. We investigated whether the most frequently examined functional variants in CCNDI determine asthma susceptibility. Materials and Methods: We genotyped 651 participants for single-nucleotide polymorphisms (SNPs) at rs9344 and rs678653 on CCND1 and assessed the association of these SNPs with asthma risk. Results: Significant differences were found in the distributions of genotypic $(p=0.0064)$ and allelic $(p=0.0021)$ frequencies of CCND1 rs9344. In addition, $A G$ or GG carriers had 0.63- or 0.48-fold adjusted odds ratios for asthma risk (95\%confidence intervals=0.48-0.92 and 0.22-0.78, respectively) than those who carried the AA wildtype. Conclusion: Our results suggest that cell cycle regulation may play a role in asthma initiation and
\end{abstract}

This article is freely accessible online.

*These Authors contributed equally to the current study.

Correspondence to: Da-Tian Bau, Terry Fox Cancer Research Laboratory, Department of Medical Research, China Medical University Hospital, 2 Yuh-Der Road, Taichung, 404 Taiwan, R.O.C. Tel: +886 422053366 (Ext. 5805), e-mail: datian@mail.cmuh.org.tw; artbau2@gmail.com

Key Words: Asthma, CCND1, cyclin D1, genotype, polymorphism, Taiwan. development, and the CCND1 rs9344 genotype may serve as an early detection marker for asthma.

Asthma is a complex airway disease characterized by eosinophilic infiltration, airflow obstruction, mucus hypersecretion, goblet cell hyperplasia, and airway hyperresponsiveness and remodeling. According to a report by the World Allergy Organization, up to 300 million people suffer from asthma, and its prevalence continues to increase. Thus, asthma is a worldwide health problem (1). Clinically, asthmatic patients usually present with wheezing, cough, and dyspnea. Asthma has an estimated heritability higher than $60 \%(2,3)$, but due to high immunological and phenotypical variations among asthmatic patients, asthma is considerably heterogeneous (4). Studies conducted in an animal disease model have suggested that approximately 200 genes are closely related to the etiology of asthma (5). Moreover, a multitude of environmental risk factors, including indoor and outdoor allergens, pollutants, smog, and air particles, may all contribute to higher risk of asthma. To date, a rather substantial body of evidence has documented typical structural alterations in the airways and lung parenchyma among asthmatic patients. These lines of evidence show that abnormal hypertrophy and hyperplasia of airway cells, such as goblet cells, smooth muscle cells, fibroblasts, and epithelial cells, take part in the processes of airway remodeling in asthma (6-10). At the molecular level, the proliferation of these human airway cells is controlled by cell cycle regulatory genes. It is possible that the genotypes of cell cycle regulatory genes may determine the personal 
susceptibility to asthma and serve as predictive biomarkers. However, related reports are extremely few.

It is well known that one of the characteristics of cancer cells is cell cycle deregulation, while cyclin D1 (encoded by the $C C N D 1$ gene) may play an important role in the initiation of tumorigenesis and cancer progression (11). Teaming up with other cyclins and their dependent kinases, cyclin D1 is the gatekeeper protein critically responsible for regulating the transition from the $\mathrm{G} 1$ phase to the $\mathrm{S}$ phase of the cell cycle (12). In other words, cyclin D1 is the major determinant of cell fate among cell proliferation, cell cycle arrest, and cell death (13-16). Variations at the genomic level, including variant gene amplification, posttranscriptional or posttranslational modifications, gene rearrangements, and polymorphic genotypes of $C C N D 1$, may result in abnormal expression levels and/or dysfunction of cyclin D1, leading to higher risk of cancer (17-21).

In 2010, Du and colleagues transfected an antisense CCND1 and abolished the phorbol myristate acetate-induced transition from $\mathrm{G} 1$ to $\mathrm{S}$ phase and the proliferation of human airway smooth muscle cells (22). It has also been demonstrated that the genotypes of the rs9433 polymorphism in CCND1, combined with particulate matter (PM10) air pollution, modify the degree to which improved air quality may benefit respiratory function in adults in a Swiss population (23).

To date, there has only been one study investigating the association of CCND1 genotype with asthma risk (24). The authors found that the CCND1 rs9344 GG genotype is a protective factor, and obesity status may increase the influence of CCNDI on asthma susceptibility (24). Based on their positive findings, we became interested in revealing the genotypic distribution of CCND1 rs9344 and rs678653 among asthmatic and non-asthmatic Taiwanese and to evaluate their potential to serve as predictive markers for asthma risk determination in Taiwan.

\section{Materials and Methods}

Recruitment of participants into asthmatic and non-asthmatic control groups. A total of 198 asthmatic patients were identified at the China Medical University Hospital in central Taiwan. Briefly, their medical histories and clinical data were collected and added to the asthmatic database. In the same period, 453 healthy individuals, age-matched ( \pm 5 years) with asthmatic patients admitted to the same hospital for routine health examinations (confirmed to reside in similar residential areas and of Taiwanese nationality), without any diagnosis of neoplastic disease or any malignancy, were manually enrolled into our age- and gender-matched control group. All the participants enrolled in this study were asked to provide informed consent to the use of their tissue and data, while all the experimental protocols were approved and supervised by Human Research Committees of China Medical University hospital (CMUH106REC1-004). After individual interview, 5-ml blood samples were collected for further DNA extraction, CCND1 genotyping, and statistical analysis.
Table I. Bone mineral density and bone metabolism-related markers of 47 patients.

\begin{tabular}{|c|c|c|c|c|c|}
\hline \multirow[t]{2}{*}{ Index } & \multicolumn{2}{|c|}{ Controls $(\mathrm{n}=453)$} & \multicolumn{2}{|c|}{ Cases $(n=198)$} & \multirow[t]{2}{*}{$p$-Value } \\
\hline & $\mathrm{n}$ & $\%$ & $\mathrm{n}$ & $\%$ & \\
\hline \multicolumn{6}{|c|}{ Age (years) } \\
\hline $25-40$ & 285 & $63.4 \%$ & 133 & $67.2 \%$ & \\
\hline$>40$ & 168 & $36.6 \%$ & 65 & $32.8 \%$ & 0.2972 \\
\hline \multicolumn{6}{|l|}{ Gender } \\
\hline Male & 190 & $41.9 \%$ & 83 & $41.9 \%$ & \\
\hline Female & 263 & $58.1 \%$ & 115 & $58.1 \%$ & 0.9956 \\
\hline
\end{tabular}

aBased on chi-square without Yate's correction test.

CCND1 rs9344 and rs678653 genotyping procedures. Genomic DNA was extracted from each person's peripheral blood leukocytes within $24 \mathrm{~h}$ after collection, carefully quantitated, diluted, and stored in a $-80^{\circ} \mathrm{C}$ freezer as previously described (25-27). The genotypic patterns at CCND1 rs9344 were determined for all subjects by typical polymerase chain reaction-restriction fragment length polymorphism (PCR-RFLP) analysis as in our previous publications $(28,29)$.

The primer sequences for $C C N D 1$ rs9344 were: forward 5'-GTG AAG TTC ATT TCC AAT CCG C-3' and reverse 5'-GGG ACATCA CCC TCA CTTAC-3'; those for CCND1 rs678653 were: forward 5'CTC TTG GTT ACA GTA GCG TAG C-3' and reverse 5'-ATC GTA GGA GTG GGA CAG GT-3'. The PCR reaction conditions were: 1) an initial denaturation at $94^{\circ} \mathrm{C}$ for $5 \mathrm{~min}$; 2) 40 cycles of $94^{\circ} \mathrm{C}$ for 30 $\mathrm{s}, 55^{\circ} \mathrm{C}$ for $30 \mathrm{~s}$, and $72^{\circ} \mathrm{C}$ for $30 \mathrm{~s}$; and 3) a final extension at $72^{\circ} \mathrm{C}$ for 10 min that was repeated twice. After PCR, the resultant 167-bp PCR products of the CCND1 rs 9344 were mixed with $2 \mathrm{U} \mathrm{Nci}$ I and incubated for $3 \mathrm{~h}$ at $37^{\circ} \mathrm{C}$. The G-allele PCR products can be further digested, while the products of the A allele cannot. Two fragments, 145 and $22 \mathrm{bp}$, are present if the product contained the $\mathrm{G}$ allele. As for CCND1 rs678653, the resultant 159-bp PCR products were mixed with $2 \mathrm{U} \mathrm{Hae}$ III and incubated for $3 \mathrm{~h}$ at $37^{\circ} \mathrm{C}$. On digestion with Hae III, the PCR product arising from the G allele was digested into fragments of 111,26 , and $22 \mathrm{bp}$, whereas the $\mathrm{C}$ allele was digested into fragments of 137 and $22 \mathrm{bp}$. Then, $10 \mu \mathrm{l}$ of the products from each subject were separated by $3 \%$ agarose gel electrophoresis. All genotyping procedures were conducted at least in duplicate by a minimum of two different researchers listed in the Acknowledgments, independently and blindly, and the results were in $100 \%$ agreement with each other.

CCND1 rs9344 and rs678653 genotype analysis methods. An unpaired Student's $t$-test was applied for the comparison of age index between the asthmatic and non-asthmatic groups. Pearson's Chisquare was applied to compare the distributions of values among subgroups. The associations between $C C N D 1$ genotypes and asthma were estimated via odds ratios (ORs) and $95 \%$ confidence intervals (CIs). Any difference was taken as significant when $p$-value $<0.05$.

\section{Results}

The frequency distributions of selected demographic indexes, such as age and gender, for the 198 asthmatic patients and 
Table II. Distributions of CCND1 rs9344 and rs678653 genotypes among asthmatic patients and non-asthmatic controls.

\begin{tabular}{ccccc}
\hline Genotype & $\begin{array}{c}\text { Asthmatic } \\
\text { cases, n (\%) }\end{array}$ & $\begin{array}{c}\text { Non-asthmatic } \\
\text { controls, n (\%) }\end{array}$ & $\begin{array}{c}\text { Adjusted OR } \\
(95 \% \mathrm{CI})^{\mathrm{a}}\end{array}$ & $p$-Value $^{\mathrm{b}}$ \\
\hline rs9344 & & & & \\
AA & $82(41.4)$ & $136(30.0)$ & 1.00 (Reference) & \\
AG & $95(48.0)$ & $238(52.5)$ & $0.63(0.48-0.92)$ & $0.0255^{*}$ \\
GG & $21(10.6)$ & $79(17.5)$ & $0.48(0.22-0.78)$ & $0.0033^{*}$ \\
GG+AG & $116(58.6)$ & $317(70.0)$ & $0.62(0.42-0.88)$ & $0.0046^{*}$ \\
$\mathrm{P}_{\text {trend }}$ & & & & $0.0064^{*}$ \\
$\mathrm{P}_{\text {HE }}$ & & & & 0.1497 \\
r678653 & & & & \\
GG & $135(68.2)$ & $317(70.0)$ & $1.00($ Reference) & \\
CG & $53(26.8)$ & $119(26.2)$ & $1.08(0.72-1.59)$ & 0.8179 \\
CC & $10(5.0)$ & $17(3.8)$ & $1.42(0.65-3.15)$ & 0.4309 \\
CC+CG & $63(31.8)$ & $136(30.0)$ & $1.07(0.78-1.52)$ & 0.6472 \\
$P_{\text {trend }}$ & & & & 0.7274 \\
P $_{\text {HWE }}$ & & & & 0.1719 \\
\hline
\end{tabular}

OR: Odds ratio; CI: confidence interval; HWE: Hardy-Weinberg Equilibrium; aData has been adjusted for confounding factors for asthma including age, gender and smoking. bBased on Chi-square test without Yates' correction; *Statistically significant.

453 non-asthmatic controls are compared and presented in Table I. Since we matched all controls and cases by age and gender, there was no difference in age and gender distribution between the case and control groups $(p=0.2972$ and 0.9956 , respectively) (Table I).

In Table II, the distributions of the genetic frequencies of the $C C N D 1$ rs9344 and rs678653 among asthmatic patients and non-asthmatic healthy controls are shown. Interestingly, the results showed that the genetic frequencies of CCND1 rs9344 were differentially distributed between the case and control groups $(p=0.0064)$. The adjusted ORs of the variant $\mathrm{AG}$ and $\mathrm{GG}$ were $0.63(95 \% \mathrm{CI}=0.48-0.92)$ and 0.48 (95\% CI $=0.22-0.78)$, respectively, compared with the AA genotype. The results obtained by comparing the combined AG+GG with the AA genotype (adjusted $\mathrm{OR}=0.62$, $95 \% \mathrm{CI}=0.42-0.88$ ) also suggested that people with the AG or GG genotypes were at lower risk than those with the AA genotype ( $p=0.0046)$ (Table II, top part). In contrast, there was no such differential distribution of the CCND1 rs678653 genotypes (Table II, bottom part).

In Table III, the allelic frequencies of the CCNDI rs9344 and rs678653 polymorphisms among asthmatic patients and non-asthmatic healthy controls are shown. The allelic frequencies of $C C N D 1$ rs 9344 were differentially distributed between the asthmatic and control groups $(p=0.0021)$. In detail, people with the $\mathrm{G}$ allele at CCND1 rs9344 had a lower asthma risk than those with the A allele after adjustment for age, gender, and smoking status (adjusted $\mathrm{OR}=0.70,95 \% \mathrm{CI}=0.52-0.78)$. In contrast, neither the genetic
Table III. Distributions of CCND1 rs9344 and rs678653 genotypes among asthmatic patients and non-asthmatic controls.

\begin{tabular}{lcccc}
\hline $\begin{array}{l}\text { Allelic } \\
\text { type }\end{array}$ & $\begin{array}{c}\text { Asthmatic } \\
\text { cases, n (\%) }\end{array}$ & $\begin{array}{c}\text { Non-asthmatic } \\
\text { controls, n (\%) }\end{array}$ & $\begin{array}{c}\text { Adjusted OR } \\
(95 \% \mathrm{CI})^{\mathrm{a}}\end{array}$ & $p$-Value \\
\hline rs9344 & & & & \\
$\quad$ Allele A & $259(65.4)$ & $510(56.3)$ & 1.00 (Reference) & \\
Allele G & $137(34.6)$ & $396(43.7)$ & $0.70(0.52-0.78)$ & $0.0021^{*}$ \\
rs678653 & & & & \\
Allele G & $323(81.6)$ & $753(83.1)$ & 1.00 (Reference) & \\
Allele C & $73(18.4)$ & $153(16.9)$ & $1.13(0.86-1.87)$ & 0.4978 \\
\hline
\end{tabular}

OR: Odds ratio; CI: confidence interval. aData has been adjusted for confounding factors for asthma including age, gender and smoking. bBased on Chi-square test without Yates' correction; *Statistically significant.

nor the allelic frequency of CCND1 rs678653 were differentially distributed between the two groups (Table III).

\section{Discussion}

Asthma is a chronic inflammatory disorder of the airways. Potential inflammatory markers for its early detection and prediction in asthmatic adult patients in Taiwan have been revealed, including interleukin-10 rs3021097 (30) and interleukin-12 rs568408 (31), whereas some others are not (30-32). However, little is known about the contribution of individual genotypes of cell cycle regulation genes to asthma risk. In the current study, we investigated the association of CCND1 rs9344 and rs678653 genotypes and asthma risk in a representative Taiwanese population including 198 asthmatic cases and 453 non-asthmatic controls. The main study findings include 1) subjects carrying the $A G$ and $G G$ genotypes (or allele G), were at of lower risk of asthma compared with those carrying the wild-type AA genotype (or A allele) on CCND1 rs9344 (Tables II and III); 2) as for CCND1 rs678653, no significantly differential distribution of genotypic or allelic frequencies was found (Tables II and III).

The single-nucleotide polymorphism in CCND1 rs9344 has been functionally well examined and found to be associated with the risk of many cancer types (33-37). It has also been associated with the risk of colorectal cancer (38), triple-negative breast cancer (39), lung cancer (40), and oral cancer (41), but not gastric cancer (42), in Taiwan. Cyclin D1 is found over-expressed in several types of epithelial cancers, such as colorectal carcinomas, and an increase in cyclin D1 not only contributes to elevated mismatch repair errors and microsatellite instability but also to tumor progression $(43,44)$.

The current study is the second to reveal that the CCNDI rs9344 genotype is associated with asthma risk. These results are consistent with previous findings of the only study 
focused on the association of CCND1 rs9344 genotype with asthma risk, which proposed that the A allele of the CCNDI rs 9344 polymorphism may serve as a risk factor for asthma (24). In that article, the authors went further to propose two important issues: 1) cell cycle genes such as CCND1 may interact with obesity to determine asthma susceptibility and severity; 2) the CCND1 rs9344 genotype is associated with physician-diagnosed asthma but not with current asthma (24). The actual mechanisms through which the A allele of CCND1 rs9344 acts to determine personal asthma susceptibility remains largely unknown. Since CCND1 rs9344 is an intronic polymorphism, it has been postulated that the polymorphic variants result in differences in alternative splicing. There is evidence showing that the A allele of CCND1 rs9344 may be related to higher expression levels of mRNA than the $G$ allele and responsible for encoding a protein with a truncated C-terminal domain (45, 46). The resulting cyclin D1 with an altered C-terminal domain is longer than the gene product of $\mathrm{G}$ allele, which may alter the accuracy of the G1/S cell cycle check point, lead to dysfunctional cell proliferation, and cause the overall airway remodeling $(47,48)$. In the future, more investigations about the clinical features, asthma severity, and genetic-environmental interactions in asthma are urgently needed.

In summary, the CCND1 rs9344 genotype may determine personal susceptibility to asthma in Taiwan. The results provide evidence supporting the notion that the genotypes of cell cycle regulators such as those of CCND1 rs9344 examined here may be involved in the asthma development. Most interestingly, the A allele of CCND1 rs9344 may serve as a predictive marker for higher risk of asthma in Taiwan.

\section{Conflicts of Interest}

The Authors declare no conflicts of interest in relation to this study.

\section{Authors' Contributions}

Research design was performed by LCH, CKL and HTC. Patient and questionnaire summaries were provided by LCH, STC and HTC. Experimental work was conducted by YCC, CWS, and TCW. Statistical analysis was performed by CLH, MMC, and TCW. LCH and BDT wrote the manuscript, whereas BDT reviewed it and all Authors are responsible for the revision.

\section{Acknowledgements}

This study was supported by research grants from Taichung Tzu Chi Hospital (TTCRD110-01) and China Medical University Hospital and Asia University (CMU109-ASIA-05). The assistance from Drs. in the Chest Department in sample and questionnaire collection, and the genotyping and analyzing of the work of Yu-Hsin Lin, Yi-Ru Huang, Yu-Ting Chin and Tai-Lin Huang are highly appreciated by all the Authors.

\section{References}

1 Mattiuzzi C and Lippi G: Worldwide asthma epidemiology: insights from the Global Health Data Exchange database. Int Forum Allergy Rhinol 10(1): 75-80, 2020. PMID: 31645084. DOI: $10.1002 /$ alr.22464

2 Duffy DL, Martin NG, Battistutta D, Hopper JL and Mathews JD: Genetics of asthma and hay fever in Australian twins. Am Rev Respir Dis 142(6 Pt 1): 1351-1358, 1990. PMID: 2252253. DOI: 10.1164/ajrccm/142.6_Pt_1.1351

3 Edfors-Lubs ML: Allergy in 7000 twin pairs. Acta Allergol 26(4): 249-285, 1971. PMID: 4255830. DOI: 10.1111/j.13989995.1971.tb01300.x

4 Strina A, Barreto ML, Cooper PJ and Rodrigues LC: Risk factors for non-atopic asthma/wheeze in children and adolescents: a systematic review. Emerg Themes Epidemiol 11: 5, 2014. PMID: 24963333. DOI: 10.1186/1742-7622-11-5

5 Temesi G, Virág V, Hadadi E, Ungvári I, Fodor LE, Bikov A, Nagy A, Gálffy G, Tamási L, Horváth I, Kiss A, Hullám G, Gézsi A, Sárközy P, Antal P, Buzás E and Szalai C: Novel genes in human asthma based on a mouse model of allergic airway inflammation and human investigations. Allergy Asthma Immunol Res 6(6): 496-503, 2014. PMID: 25374748. DOI: 10.4168/aair.2014.6.6.496

6 Aikawa T, Shimura S, Sasaki H, Ebina M and Takishima T: Marked goblet cell hyperplasia with mucus accumulation in the airways of patients who died of severe acute asthma attack. Chest 101(4): 916-921, 1992. PMID: 1555462. DOI: 10.1378/chest.101.4.916

7 Carroll N, Elliot J, Morton A and James A: The structure of large and small airways in nonfatal and fatal asthma. Am Rev Respir Dis 147(2): 405-410, 1993. PMID: 8430966. DOI: 10.1164/ ajrccm/147.2.405

8 Johnson PR, Roth M, Tamm M, Hughes M, Ge Q, King G, Burgess JK and Black JL: Airway smooth muscle cell proliferation is increased in asthma. Am J Respir Crit Care Med 164(3): 474-477, 2001. PMID: 11500353. DOI: 10.1164/ajrccm. 164.3.2010109

9 Kraft M, Lewis C, Pham D and Chu HW: IL-4, IL-13, and dexamethasone augment fibroblast proliferation in asthma. J Allergy Clin Immunol 107(4): 602-606, 2001. PMID: 11295646. DOI: $10.1067 /$ mai.2001.113760

10 Cohen L, E X, Tarsi J, Ramkumar T, Horiuchi TK, Cochran R, DeMartino S, Schechtman KB, Hussain I, Holtzman MJ, Castro $M$ and NHLBI Severe Asthma Research Program (SARP): Epithelial cell proliferation contributes to airway remodeling in severe asthma. Am J Respir Crit Care Med 176(2): 138-145, 2007. PMID: 17463414. DOI: 10.1164/rccm. 200607-1062OC

11 Motokura T, Bloom T, Kim HG, Jüppner H, Ruderman JV, Kronenberg HM and Arnold A: A novel cyclin encoded by a bcl1-linked candidate oncogene. Nature 350(6318): 512-515, 1991. PMID: 1826542. DOI: 10.1038/350512a0

12 Walker JL and Assoian RK: Integrin-dependent signal transduction regulating cyclin D1 expression and G1 phase cell cycle progression. Cancer Metastasis Rev 24(3): 383-393, 2005. PMID: 16258726. DOI: 10.1007/s10555-005-5130-7

13 Hunter T and Pines J: Cyclins and cancer II: Cyclin D and CDK inhibitors come of age. Cell 79(4): 573-582, 2020. DOI: 10.1016/0092-8674(94)90543-6 
14 Malumbres $\mathrm{M}$ and Barbacid M: To cycle or not to cycle: a critical decision in cancer. Nat Rev Cancer 1(3): 222-231, 2001. PMID: 11902577. DOI: $10.1038 / 35106065$

15 Ortega S, Malumbres M and Barbacid M: Cyclin D-dependent kinases, INK4 inhibitors and cancer. Biochim Biophys Acta 1602(1): 73-87, 2002. PMID: 11960696. DOI: 10.1016/s0304$419 x(02) 00037-9$

16 Cook SJ, Balmanno K, Garner A, Millar T, Taverner C and Todd D: Regulation of cell cycle re-entry by growth, survival and stress signalling pathways. Biochem Soc Trans 28(2): 233-240, 2000. PMID: 10816134. DOI: 10.1042/bst0280233

17 Jayasurya R, Sathyan KM, Lakshminarayanan K, Abraham T, Nalinakumari KR, Abraham EK, Nair MK and Kannan S: Phenotypic alterations in $\mathrm{Rb}$ pathway have more prognostic influence than p53 pathway proteins in oral carcinoma. Mod Pathol 18(8): 1056-1066, 2005. PMID: 15731778. DOI: 10.1038/modpathol.3800387

18 Bova RJ, Quinn DI, Nankervis JS, Cole IE, Sheridan BF, Jensen MJ, Morgan GJ, Hughes CJ and Sutherland RL: Cyclin D1 and p16INK4A expression predict reduced survival in carcinoma of the anterior tongue. Clin Cancer Res 5(10): 2810-2819, 1999. PMID: 10537346.

19 Michalides R, van Veelen N, Hart A, Loftus B, Wientjens E and Balm A: Overexpression of cyclin D1 correlates with recurrence in a group of forty-seven operable squamous cell carcinomas of the head and neck. Cancer Res 55(5): 975-978, 1995. PMID: 7867006.

$20 \mathrm{Wu}$ Y, Fu H, Zhang H, Huang H, Chen M, Zhang L, Yang H and Qin D: Cyclin D1 (CCND1) G870A polymorphisms and cervical cancer susceptibility: a meta-analysis based on ten case-control studies. Tumour Biol 35(7): 6913-6918, 2014. PMID: 24737585. DOI: $10.1007 / \mathrm{s} 13277-014-1929-6$

21 Vízkeleti L, Ecsedi S, Rákosy Z, Orosz A, Lázár V, Emri G, Koroknai V, Kiss T, Ádány R and Balázs M: The role of CCND1 alterations during the progression of cutaneous malignant melanoma. Tumour Biol 33(6): 2189-2199, 2012. PMID: 23001925. DOI: 10.1007/s13277-012-0480-6

22 Du CL, Xu YJ, Liu XS, Xie JG, Xie M, Zhang ZX, Zhang J and Qiao LF: Up-regulation of cyclin D1 expression in asthma serum-sensitized human airway smooth muscle promotes proliferation via protein kinase $\mathrm{C}$ alpha. Exp Lung Res 36(4): 201-210, 2010. PMID: 20426528. DOI: 10.3109/ 01902140903290022

23 Imboden M, Schwartz J, Schindler C, Curjuric I, Berger W, Liu SL, Russi EW, Ackermann-Liebrich U, Rochat T, Probst-Hensch NM and SAPALDIA Team: Decreased PM10 exposure attenuates age-related lung function decline: genetic variants in p53, p21, and CCND1 modify this effect. Environ Health Perspect 117(9): 1420-1427, 2009. PMID: 19750108. DOI: 10.1289/ehp.0800430

24 Thun GA, Imboden M, Berger W, Rochat T and Probst-Hensch NM: The association of a variant in the cell cycle control gene CCND1 and obesity on the development of asthma in the Swiss SAPALDIA study. J Asthma 50(2): 147-154, 2013. PMID: 23311506. DOI: $10.3109 / 02770903.2012 .757776$

25 Chen GL, Wang SC, Shen TC, Chang WS, Lin C, Hsia TC, Bau DT and Tsai CW: Significant association of chitinase 3-like 1 genotypes to asthma risk in Taiwan. In Vivo 35(2): 799-803, 2021. PMID: 33622872. DOI: 10.21873 /invivo. 12320

26 Chen LH, Shen TC, Li CH, Chiu KL, Hsiau YC, Wang YC, Gong CL, Wang ZH, Chang WS, Tsai CW, Hsia TC and Bau
DT: The significant interaction of excision repair crosscomplementing group 1 genotypes and smoking to lung cancer risk. Cancer Genomics Proteomics 17(5): 571-577, 2020. PMID: 32859635. DOI: $10.21873 / \operatorname{cgp} .20213$

27 Pei JS, Chang WS, Hsu PC, Chen CC, Chin YT, Huang TL, Hsu YN, Kuo CC, Wang YC, Tsai CW, Gong CL and Bau DT: Significant association between the MiR146a genotypes and susceptibility to childhood acute lymphoblastic leukemia in Taiwan. Cancer Genomics Proteomics 17(2): 175-180, 2020. PMID: 32108040. DOI: $10.21873 / \mathrm{cgp} .20178$

28 Shih LC, Tsai CW, Chang WS, Shen TC, Wang YC, Yang JS, Lin ML, Wang ZH and Bau DT: Association of caspase-8 genotypes with the risk for nasopharyngeal carcinoma in Taiwan. Anticancer Res 40(10): 5503-5508, 2020. PMID: 32988873. DOI: 10.21873 /anticanres.14562

29 Shih LC, Chang WS, Lee HT, Wang YC, Wang ZH, Chao CY, Yu CC, Lin HY, Shen TC, Kuo CC, Tsai CW and Bau DT: Interaction of interleukin-16 genotypes with betel quid chewing behavior on oral cancer in Taiwan. In Vivo 34(4): 1759-1764, 2020. PMID: 32606144. DOI: 10.21873/invivo.11969

30 Hsia TC, Chang WS, Wang S, Shen TC, Hsiao WY, Liu CJ, Liang SJ, Chen WC, Tu CY, Tsai CW, Hsu CM and Bau DT: The contribution of interleukin-10 promoter genotypes to susceptibility to asthma in adults. In Vivo 29(6): 695-699, 2015. PMID: 26546526.

31 Shen TC, Tsai CW, Chang WS, Wang S, Chao CY, Hsiao CL, Chen WC, Hsia TC and Bau DT: Association of interleukin-12A rs568408 with susceptibility to asthma in Taiwan. Sci Rep 7(1): 3199, 2017. PMID: 28600552. DOI: 10.1038/s41598-01703523-0

32 Hsiao WY, Tsai CW, Chang WS, Wang S, Chao CY, Chen WC, Shen TC, Hsia TC and Bau DT: Association of polymorphisms in DNA repair gene XRCC3 with asthma in Taiwan. In Vivo 32(5): 1039-1043, 2018. PMID: 30150425. DOI: 10.21873/ invivo.11344

33 Yang Y, Shu X, Shu XO, Bolla MK, Kweon SS, Cai Q, Michailidou K, Wang Q, Dennis J, Park B, Matsuo K, Kwong A, Park SK, Wu AH, Teo SH, Iwasaki M, Choi JY, Li J, Hartman M, Shen CY, Muir K, Lophatananon A, Li B, Wen W, Gao YT, Xiang YB, Aronson KJ, Spinell JJ, Gago-Dominguez M, John EM, Kurian AW, Chang-Claude J, Chen ST, Dörk T, Evans DGR, Schmidt MK, Shin MH, Giles GG, Milne RL, Simard J, Kubo M, Kraft P, Kang D, Easton DF, Zheng W and Long J: Re-evaluating genetic variants identified in candidate gene studies of breast cancer risk using data from nearly 280,000 women of Asian and European ancestry. EBioMedicine 48: 203211, 2019. PMID: 31629678. DOI: 10.1016/j.ebiom.2019.09.006

34 Qiu H, Cheng C, Wang Y, Kang M, Tang W, Chen S, Gu H, Liu $\mathrm{C}$ and Chen Y: Investigation of cyclin D1 rs9344 G>A polymorphism in colorectal cancer: a meta-analysis involving 13,642 subjects. Onco Targets Ther 9: 6641-6650, 2016. PMID: 27822068. DOI: $10.2147 /$ OTT.S116258

35 Sabir M, Baig RM, Mahjabeen I and Kayani MA: Significance of cyclin D1 polymorphisms in patients with head and neck cancer. Int J Biol Markers 28(1): 49-55, 2013. PMID: 23125009. DOI: $10.5301 / \mathrm{JBM} .2012 .9768$

36 Castro FA, Haimila K, Sareneva I, Schmitt M, Lorenzo J, Kunkel N, Kumar R, Försti A, Kjellberg L, Hallmans G, Lehtinen M, Hemminki K and Pawlita M: Association of HLADRB1, interleukin-6 and cyclin D1 polymorphisms with cervical 
cancer in the Swedish population - a candidate gene approach. Int J Cancer 125(8): 1851-1858, 2009. PMID: 19585495. DOI: $10.1002 /$ ijc. 24529

37 Wang N, Qian X, Wang S, Gao H, Wang L, Huo Y and Zhang S: CCND1 rs9344 polymorphisms are associated with the genetic susceptibility to cervical cancer in Chinese population. Mol Carcinog 51(2): 196-205, 2012. PMID: 21594903. DOI: $10.1002 / \mathrm{mc} .20801$

38 Huang CY, Tsai CW, Hsu CM, Chang WS, Shui HA and Bau DT: The significant association of CCND1 genotypes with colorectal cancer in Taiwan. Tumour Biol 36(8): 6533-6540, 2015. PMID: 25809706. DOI: 10.1007/s13277-015-3347-9

39 Liu LC, Su CH, Wang HC, Chang WS, Tsai CW, Maa MC, Tsai $\mathrm{CH}$, Tsai FJ and Bau DT: Contribution of personalized Cyclin D1 genotype to triple negative breast cancer risk. Biomedicine (Taipei) 4: 3, 2014. PMID: 25520916. DOI: 10.7603/s40681014-0003-4

40 Hsia TC, Liu CJ, Lin CH, Chang WS, Chu CC, Hang LW, Lee HZ, Lo WC and Bau DT: Interaction of CCND1 genotype and smoking habit in Taiwan lung cancer patients. Anticancer Res 31(10): 3601-3605, 2011. PMID: 21965784.

41 Tsai MH, Tsai CW, Tsou YA, Hua CH, Hsu CF and Bau DT: Significant association of cyclin D1 single nucleotide polymorphisms with oral cancer in Taiwan. Anticancer Res 31(1): 227-231, 2011. PMID: 21273603.

42 Kuo HW, Huang CY, Fu CK, Liao CH, Hsieh YH, Hsu CM, Tsai $\mathrm{CW}$, Chang WS and Bau DT: The significant association of CCND1 genotypes with gastric cancer in Taiwan. Anticancer Res 34(9): 4963-4968, 2014. PMID: 25202078.
43 Donnellan R and Chetty R: Cyclin D1 and human neoplasia. Mol Pathol 51(1): 1-7, 1998. PMID: 9624412. DOI: 10.1136/ mp.51.1.1

44 Bala S and Peltomäki P: CYCLIN D1 as a genetic modifier in hereditary nonpolyposis colorectal cancer. Cancer Res 61(16): 6042-6045, 2001. PMID: 11507050.

45 Fan YZ, Fu JY, Zhao ZM and Chen CQ: Inhibitory effect of norcantharidin on the growth of human gallbladder carcinoma GBC-SD cells in vitro. Hepatobiliary Pancreat Dis Int 6(1): 7280, 2007. PMID: 17287171

46 Sobti RC, Kaur P, Kaur S, Singh J, Janmeja AK, Jindal SK, Kishan J and Raimondi S: Effects of cyclin D1 (CCND1) polymorphism on susceptibility to lung cancer in a North Indian population. Cancer Genet Cytogenet 170(2): 108-114, 2006. PMID: 17011980. DOI: 10.1016/j.cancergencyto.2006.05.017

47 Lu C, Dong J, Ma H, Jin G, Hu Z, Peng Y, Guo X, Wang X and Shen H: CCND1 G870A polymorphism contributes to breast cancer susceptibility: a meta-analysis. Breast Cancer Res Treat 116(3): 571-575, 2009. PMID: 18819000. DOI: 10.1007/s10549$008-0195-\mathrm{y}$

48 Li Z, Jiao X, Wang C, Shirley LA, Elsaleh H, Dahl O, Wang M, Soutoglou E, Knudsen ES and Pestell RG: Alternative cyclin D1 splice forms differentially regulate the DNA damage response. Cancer Res 70(21): 8802-8811, 2010. PMID: 20940395. DOI: 10.1158/0008-5472.CAN-10-0312

Received April 20, 2021

Revised May 3, 2021

Accepted May 4, 2021 